Article

\title{
Effects of Tannic Acid on Lipid and Protein Oxidation, Color, and Volatiles of Raw and Cooked Chicken Breast Meat during Storage
}

\author{
Marwan Al-Hijazeen ${ }^{1}$, Eun Joo Lee ${ }^{2, *}$, Aubrey Mendonca ${ }^{3}$ and Dong Uk Ahn ${ }^{1}$ \\ 1 Department of Animal Science, Iowa State University, Ames, IA 50011, USA; \\ marwana@mutah.edu.jo (M.A.-H.); duahn@iastate.edu (D.U.A.) \\ 2 Department of Food and Nutrition, University of Wisconsin-Stout, Menomonie, WI 54751, USA \\ 3 Department of Food Science and Human Nutrition, Iowa State University, Ames, IA 50011, USA; \\ amendon@iastate.edu \\ * Correspondence: leeeu@uwstout.edu; Tel.: +1-715-232-1623; Fax: +1-715-232-2317
}

Academic Editor: David Arráez-Román

Received: 28 April 2016; Accepted: 4 June 2016; Published: 13 June 2016

\begin{abstract}
The objective of this study was to determine the effect of tannic acid (TA) on the oxidative stability and the quality characteristics of ground chicken breast meat. Five treatments including (1) control (none added), (2) 2.5 ppm TA, (3) 5 ppm TA, (4) 10 ppm TA, and (5) 5 ppm butylated hydroxyanisole (BHA) were added to boneless, skinless ground chicken breast meat, and used for both raw and cooked meat studies. For the raw meat study, the ground chicken breast meat was packaged in oxygen-permeable bags and stored at $4{ }^{\circ} \mathrm{C}$ for 7 days. For the cooked study, raw ground meat samples were vacuum-packaged in oxygen-impermeable vacuum bags, cooked in-bag to the internal temperature of $75^{\circ} \mathrm{C}$, re-packaged in oxygen-permeable bags, and then stored. Both raw and cooked meats were analyzed for lipid and protein oxidation, color, and volatiles (cooked meat only) at 0,3 , and 7 days of storage. Raw meats with $10 \mathrm{ppm}$ of TA added had significantly $(p \leqslant 0.05)$ lower lipid and protein oxidation than other treatments during storage. In addition, TA at $10 \mathrm{ppm}$ level maintained the highest color $\mathrm{a}^{*}$ - and $\mathrm{L}^{*}$-values during storage. Cooked chicken breast meat with 5 and 10 ppm TA added produced significantly $(p \leqslant 0.05)$ lower amounts of off-odor volatiles than other treatments. Among the volatile compounds, the amount of hexanal increased rapidly during storage for cooked meat. However, meats with 5 and $10 \mathrm{ppm}$ TA added showed the lowest amount of hexanal and other aldehydes related to lipid oxidation, indicating a strong antioxidant effect of TA in cooked chicken breast meat. Furthermore, the differences in aldehydes among the treatments were bigger in cooked than in raw meat, indicating that the antioxidant effect of TA in cooked meat was greater than that in raw meat. Therefore, TA at $>5 \mathrm{ppm}$ can be used as a good natural preservative in cooked chicken meat to maintain its quality during storage.
\end{abstract}

Keywords: chicken breast meat; tannic acid; lipid oxidation; protein oxidation; volatiles; color

\section{Introduction}

The use of synthetic antioxidants is discouraged due to their potential adverse effects on human health, and the poultry meat industry is actively seeking natural antioxidants to replace the synthetic ones. Several natural antioxidants from plants showed positive effects in improving meat quality and extending shelf life [1-4].

Meat color and odor are important attributes for the consumer evaluation on meat quality $[5,6]$. Usually, fresh meat is characterized by a cherry-red color due to the formation of oxymyoglobin (OxyMb). However, oxidation of the heme pigment will convert the red color to brown [7]. Lipid 
oxidation is considered as the major problem affecting meat quality [8] because it changes color, generates off-odor [9], and impairs protein functionality [10]. Protein functionality such as solubility, emulsification, water binding capacity, and texture are also affected by lipid oxidation and their interactions with protein oxidation products [10,11].

The progress of oxidation in fresh meat depends on many internal factors such as catalyst (Iron Fe, $\mathrm{Cu}$, etc.), antioxidant capacity, $\mathrm{pH}$, fatty acid composition, and free radical formation. However, many external factors such as high storage temperature, oxygen availability, meat processing method, and additives also can influence lipid and protein oxidation in meat [12]. Therefore, finding new natural antioxidants to resolve these problems in meat and other foods is important.

Herbs and plant extracts such as rosemary [13], oregano [14], grape seed and bearberry extracts [15,16], plum extract [17], and garlic and onion oleoresins [8] have been tested to prevent lipid oxidation in meat because they contained high levels of antioxidants [4]. Plants produce a wide variety of "secondary compounds" including alkaloids, terpenes, and phenolics in their cells to protect themselves from external herbivores and diseases [18]. Among these compounds, tannins have metal-chelating, antioxidant, and protein precipitating activities [19], and show positive effects on meat color stability and extend their self-life [20].

The tannins are defined as water-soluble phenolic compounds with molecular weights between 500 and $3000 \mathrm{Da}$, and have special properties such as precipitating alkaloids, gelatin, and other proteins [21]. These properties of tannins are based on their chemical structures, which have two or three phenolic hydroxyl groups on the phenyl ring (polyphenol). Tannins are classified into two different main groups-hydrolysable and condensed tannins. The hydrolyzable type of tannins contains polyhydric alcohol and hydroxyl groups, which are esterified by gallic acid (gallotannins) or to hexahydroxy diphenic acid (ellagitannins) [22]. Condensed tannins are more complex in their structure compared to hydrolysable tannins, and are mainly produced by two main polymerized products of flavan-3-ols and flavan-3,4-diols, or a mixture of both [23].

Tannic acid is a yellowish-white to light-brown powder, and is soluble in water and alcohol (hydrolysable tannins). The antioxidant activity of tannic acid was explained by several researchers through their ability to prevent hydroxyl radical formation [24], metal-chelating activity [22], and radical-scavenging activity [25]. These activities make the tannic acid a possible replacement for synthetic antioxidants [26,27]. Tannic acid can be obtained in two different ways: (1) solvent extraction of nutgalls or excrescences from young twigs of Quercus infectoria Oliver, and (2) solvent extraction of the seed pod of Tara (Caesalpinia spinosa), or the nutgalls of various sumac species, including Rhus semialata, R. coriaria, R. galabra, and R. typhia [28]. The commercial formula for tannic acid is given as $\mathrm{C}_{76} \mathrm{H}_{52} \mathrm{O}_{46}$ and is composed of a mixture of polygalloyl glucose and polygalloyl quinnic acid ester depending on the plant extract sources and purification methods used $[18,19]$. Tannic acid is classified as generally recognized as safe (GRAS) by the Food and Drug Administration (FDA), and up to $10 \mathrm{ppm}$ of tannic acid is allowed to be used in meat products [28]. However, little work has been done to determine their effect on the storage stability and quality characteristics of ground chicken meat.

The objective of this study was to investigate the effect of adding tannic acid on the stability and quality of ground chicken meat (raw and cooked meat) during storage.

\section{Materials and Methods}

Tannic acid powder containing 90\% tannin was obtained from Sigma-Aldrich (St. Louis, MO, USA). The tannic acid contained gallic acid, monogalloyl glucose, digalloyl glucose, trigalloyl glucose, tetragalloyl glucose, pentagalloyl glucose, ESA galloyl glucose, EPTA galloyl glucose, and octagalloyl glucose. The product is hydrolyzable tannin obtained from oak gall nuts from Quercus infectoria.

\subsection{Sample Preparation}

One hundred and twenty, 6-week-old broilers raised on a corn-soybean meal diet were slaughtered using the USDA guidelines [29]. The chicken carcasses were chilled in ice water for $2 \mathrm{~h}$ and drained in 
a cold room, and the breast muscles were separated from the carcasses $24 \mathrm{~h}$ after slaughter. The breast muscles were ground twice a through a $10-\mathrm{mm}$ and a 3-mm plates (Kitchen Aid, Inc., St. Joseph, MI, USA) after removing skins before use. Five treatments including (1) control (none added), (2) 2.5 ppm tannic acid, (3) 5 ppm tannic acid, (4) 10 ppm tannic acid, and (5) 5 ppm butylated hydroxyanisole (BHA) were prepared. Tannic acid $(0.1 \mathrm{~g})$ was dissolved in $50 \mathrm{~mL}$ of de-ionized distilled water (DDW) and stored in a dark area to prevent exposure to light. BHA powder $(0.1 \mathrm{~g})$ was dissolved in $10 \mathrm{~mL}$ of $100 \%$ ethanol, and then mixed with $50 \mathrm{~mL}$ mineral oil to make a stock solution. The ethanol added was removed using a rotary evaporator (BUCH Rotavapor, Model R-200, BUCHI Co., New Castle, DE, USA) at $\left(70{ }^{\circ} \mathrm{C}, 175\right.$ mbar vacuum pressure) before adding the stock solution to meat samples. Each additive treatment was added to the ground breast meat and then mixed for 2 min in a bowl mixer (Model KSM 90; Kitchen Aid Inc., St. Joseph, MI, USA). All treatments were added with the same amounts of mineral oil to provide the same conditions.

For raw-meat study, the prepared meat samples (approximately $100 \mathrm{~g}$ each) were individually packaged in oxygen-permeable bags (polyethylene, 4" $\times 66^{\prime \prime}, 2$ mil, Associated Bag Co., Milwaukee, WI, USA), stored at $4{ }^{\circ} \mathrm{C}$ for 7 days, and analyzed for lipid and protein oxidation, and color at 0,3 , and 7 days of storage.

The same preparation method was used for cooked meat study, but the raw meat samples were vacuum packaged in oxygen-impermeable vacuum bags $\left(\mathrm{O}_{2}\right.$ permeability, $9.3 \mathrm{~mL} \mathrm{O} / \mathrm{m}^{2} / 24 \mathrm{~h}$ at $0{ }^{\circ} \mathrm{C}$, Koch, Kansas City, MO, USA), and the meats were cooked in-bag in a $90{ }^{\circ} \mathrm{C}$ water bath (Isotemp ${ }^{\circledR}$, Fisher Scientific Inc., Pittsburgh, PA, USA) until the internal temperature of the meat reached to $75^{\circ} \mathrm{C}$. After cooling to room temperature, the cooked meat was individually re-packaged in oxygen-permeable bag (polyethylene, 4" $\times 6$ 6", 2 mil, Associated Bag Co., Milwaukee, WI, USA), stored at $4{ }^{\circ} \mathrm{C}$ for 7 days, and analyzed for lipid and protein oxidation and volatiles at 0,3 , and 7 days of storage.

\subsection{2-Thiobarbituric Acid-Reactive Substances (TBARS) Measurement}

Lipid oxidation was determined using a TBARS method [30]. Five grams of ground chicken meat were weighed into a 50-mL test tube, added with $50 \mu \mathrm{L}$ BHT (7.2\%) and $15 \mathrm{~mL}$ of deionized distilled water (DDW), and homogenized using a Polytron (Type PT 10/35, Brinkman Instruments Inc., Westbury, NY, USA) for $15 \mathrm{~s}$ at high speed. One milliliter of the meat homogenate was transferred to a disposable test tube $(13 \times 100 \mathrm{~mm})$, and thiobarbituric acid/trichloroacetic acid solution $(15 \mathrm{mM}$ TBA/15\% TCA, $2 \mathrm{~mL}$ ) was added. The mixture was vortex-mixed and incubated in a boiling water bath for $15 \mathrm{~min}$ to develop color. Then, samples were cooled in ice-water for $10 \mathrm{~min}$, mixed again, and centrifuged for $15 \mathrm{~min}$ at $2500 \times \mathrm{g}$ at $4{ }^{\circ} \mathrm{C}$. The absorbance of the resulting supernatant solution was determined at $532 \mathrm{~nm}$ against a blank containing $1 \mathrm{~mL}$ of DDW and $2 \mathrm{~mL}$ of TBA/TCA solution. The amounts of TBARS were expressed as mg of malondialdehyde (MDA) per $\mathrm{kg}$ of meat.

\subsection{Color Measurement}

The color of meat was measured on the surface of meat samples using a Konica Minolta Color Meter (CR-410, Konioka Minolta, Osaka, Japan). The color meter was calibrated using an illuminant source $C$ (average daylight) on a standard white ceramic tile covered with the same packaging film as the ones used for meat samples to negate the color and light reflectance properties of the packaging material. The color was expressed as CIE L*- (lightness), $\mathrm{a}^{*}$ - (redness), and b*- (yellowness) values [31]. The areas selected for color measurement were free from obvious defects that may affect the uniform color readings. An average of two random readings on the top of the sample surface was used for statistical analysis.

\subsection{Volatile Analysis}

Volatiles of samples were analyzed using a Solatek-72 Multimatrix-Vial Auto-sampler/Sample Concentrator 3100 (Tekmar-Dohrmann, Cincinnati, OH, USA) connected to a GC/MS (Model 6890/5973; 
Hewlett-Packard Co., Wilmington, DE, USA) according to the method of Ahn et al. [32]. Sample (3 g for raw meat and $2 \mathrm{~g}$ for cooked meat) was placed in a 40-mL sample vial, flushed with helium gas (40 psi) for $3 \mathrm{~s}$, and then capped airtight with a Teflon-fluorocarbon resin/silicone septum (I-Chem Co., New Castle, DE, USA). Samples from different treatments were randomly organized on the refrigerated $\left(4{ }^{\circ} \mathrm{C}\right)$ holding trying to minimize the oxidative changes among treatments during analysis. The meat sample was purged with helium $(40 \mathrm{~mL} / \mathrm{min})$ for $14 \mathrm{~min}$ at $20^{\circ} \mathrm{C}$. Volatiles were trapped using a Tenax/charcoal/silica column (Tekmar-Dohrmann) and desorbed for $2 \mathrm{~min}$ at $225^{\circ} \mathrm{C}$, focused in a cryofocusing module $\left(-70^{\circ} \mathrm{C}\right)$, and then thermally desorbed into a capillary column for $2 \mathrm{~min}$ at $225^{\circ} \mathrm{C}$. An HP-624 column (7.5 m, 0.25 mm i.d., $1.4 \mu \mathrm{m}$ nominal), an HP-1 column ( $52.5 \mathrm{~m}, 0.25 \mathrm{~mm}$ i.d., $0.25 \mu \mathrm{m}$ nominal), and an HP-Wax column ( $7.5 \mathrm{~m}, 0.250 \mathrm{~mm}$ i.d., $0.25 \mu \mathrm{m}$ nominal) were connected using zero dead-volume column connectors (J \&W Scientific, Folsom, CA, USA). Ramped oven temperature was used to improve volatile separation. The initial oven temperature of $25^{\circ} \mathrm{C}$ was held for $5 \mathrm{~min}$. After that, the oven temperature was increased to $85^{\circ} \mathrm{C}$ at $40^{\circ} \mathrm{C}$ per min, increased to $165{ }^{\circ} \mathrm{C}$ at $20^{\circ} \mathrm{C}$ per min, and then increased to $230{ }^{\circ} \mathrm{C}$ at $5{ }^{\circ} \mathrm{C}$ per min and held for $2.5 \mathrm{~min}$ at the temperature. Constant column pressure at 22.5 psi was maintained. The ionization potential of MS was $70 \mathrm{eV}$, and the scan range was $20.1-350 \mathrm{~m} / \mathrm{z}$. The identification of volatiles was achieved by the Wiley Library (Hewlett-Packard Co., Wilmington, DE, USA). The area of each peak was integrated using ChemStation ${ }^{\mathrm{TM}}$ software (Hewlett-Packard Co., Wilmington, DE, USA), and the total peak area (total ion counts $\times 10^{4}$ ) was reported as an indicator of volatiles generated from the samples.

\subsection{Protein Oxidation (Total Carbonyl)}

Protein oxidation was determined by the method by Lund et al. [33] with minor modifications. One gram of meat sample was added to $10 \mathrm{~mL}$ of pyrophosphate buffer $\left(2.0 \mathrm{mM} \mathrm{Na}_{4} \mathrm{P}_{2} \mathrm{O}_{7}, 10 \mathrm{mM}\right.$ Trizma-maleate), $100 \mathrm{mM} \mathrm{KCL}, 2.0 \mathrm{mM} \mathrm{MgCl}_{2}$, and $2.0 \mathrm{mM}$ ethylene glycol tetraacetic acid, $\mathrm{pH} 7.4$ ) and homogenized using a Brinkman Polytron (Type PT 10/35). Two equal amounts of meat homogenate $(2 \mathrm{~mL}$ ) were taken from a sample, precipitated with $2 \mathrm{~mL}$ of $20 \%$ trichloroacetic acid, and centrifuged at $12,000 \times g$ for $5 \mathrm{~min}$ at room temperature. After centrifugation, one of the pellets was dissolved with $2 \mathrm{~mL}$ of $10 \mathrm{mM}$ 2,4-dinitrophenylhydrazine in $2 \mathrm{M} \mathrm{HCl}$ and the other one was dissolved with $2 \mathrm{M} \mathrm{HCl}$ (blank), and were incubated for $30 \mathrm{~min}$ in the dark. During the incubation, the samples were vortex-mixed for $10 \mathrm{~s}$ every $3 \mathrm{~min}$. The protein was further precipitated with $2 \mathrm{~mL}$ of $20 \%$ trichloroacetic acid and centrifuged at $12,000 \times g$ for $5 \mathrm{~min}$. The 2,4-dinitrophenylhydrazine was removed by washing the pellets 3 times with $4 \mathrm{~mL}$ of $10 \mathrm{mM} \mathrm{HCl}$ in 1:1 (vol/vol) ethanol:ethyl acetate, followed by centrifuging at $12,000 \times \mathrm{g}$ for $5 \mathrm{~min}$. The pellets were finally solubilized in $2 \mathrm{~mL}$ of $6.0 \mathrm{mM}$ guanidine hydrochloride dissolved in $20 \mathrm{mM}$ potassium dihydrogen phosphate $(\mathrm{pH}=2.3)$. The samples were kept at $5{ }^{\circ} \mathrm{C}$ overnight and centrifuged to remove insoluble materials. The absorbance of supernatants was read at $370 \mathrm{~nm}$ and the value of blank sample was subtracted from their corresponding sample value. The protein concentration of meat samples was measured using Protein Assay Kit (Bio-Rad Laboratories, Hercules, CA, USA) following Microplate Assay protocol at $280 \mathrm{~nm}$ (BioTek-Gen5 Microplate data collection \& analysis software/BioTek Instruments, Inc., Model S4MLFPTA, Winooski, VT, USA). The carbonyl content was calculated as $\mathrm{nmol} / \mathrm{mg}$ protein using absorption coefficient of $22,000 / \mathrm{M} / \mathrm{cm}$ as described by Levine et al. [34].

\subsection{Statistical Analysis}

Data were analyzed using the procedures of the generalized linear model (Proc. GLM, SAS program, version 9.3, 2012, SAS Institute Inc., Cary, NC, USA) [35]. Mean values and standard error of the means (SEM) were reported. The significance was defined at $p<0.05$ and Tukey or Tukey's Multiple Range tests were used to determine whether there is a significant difference between the mean values. 


\section{Results and Discussion}

\subsection{Lipid Oxidation}

In the raw chicken meat, there was no significant difference $(p>0.05)$ in TBARS between treatments at day 0 . In addition, tannic acid at $2.5 \mathrm{ppm}$ did not show any significant antioxidant effect on the chicken breast meat during storage. However, 5 ppm BHA or tannic acid at 5 and 10 ppm showed significant antioxidant effects after seven days of storage (Table 1). Tannic acid at 10 ppm showed the strongest antioxidant effects of all during storage. This result is in agreement with that of Maqsood and Benjakul [26] who found that tannic acid at 100-200 ppm effectively decreased both peroxide value and TBARS values in catfish slices. They found that tannic acid exhibited the highest antioxidant activities (peroxide value, conjugated diene, TBARS values) in both fish oil emulsion and fish mince among the phenolic compounds (catechin, caffeic acid, ferulic acid, and tannic acid) they had tested [27]. They explained that the high antioxidant effect of tannic acid was due to its ability to chelate non-heme iron in the fish mince. Iron is considered a strong pro-oxidant transitional metal that can increase lipid oxidation in meat. Because of their chemical structure, tannic acid inhibits hydroxyl radical formation from the Fenton reaction by complexing ferrous ions [24]. Lopes et al. [24] found that the antioxidant activity of tannic acid is mainly due to iron chelating rather than $\mathrm{OH}$-scavenging activity. Maqsood and Benjakul [20] also reported that when tannic acid $(200 \mathrm{mg} / \mathrm{kg})$ was added to the refrigerated ground beef, its peroxide and TBARS values were significantly lower than that of the control.

Table 1. 2-Thiobarbituric acid-reactive substances (TBARS) values of raw and cooked chicken breast meat with different levels of tannic acid during storage at $4{ }^{\circ} \mathrm{C}$.

\begin{tabular}{ccccccc}
\hline Time & $\begin{array}{c}\text { Control } \\
\text { (None) }\end{array}$ & $\begin{array}{c}\text { 2.5 ppm } \\
\text { Tannic }\end{array}$ & $\begin{array}{c}\text { 5 ppm } \\
\text { Tannic }\end{array}$ & $\begin{array}{c}\text { 10 ppm } \\
\text { Tannic }\end{array}$ & $\begin{array}{c}\text { 5 ppm } \\
\text { BHA }\end{array}$ & SEM \\
\hline Raw meat & \multicolumn{7}{c}{ TBARS (mg MDA/kg meat) } \\
\hline Day 0 & $0.14^{\mathrm{a}, \mathrm{z}}$ & $0.13^{\mathrm{a}, \mathrm{z}}$ & $0.13^{\mathrm{a}, \mathrm{y}}$ & $0.12^{\mathrm{a}, \mathrm{x}}$ & $0.13^{\mathrm{a}, \mathrm{y}}$ & 0.01 \\
Day 3 & $0.18^{\mathrm{a}, \mathrm{y}}$ & $0.17^{\mathrm{a}, \mathrm{y}}$ & $0.15^{\mathrm{ab}, \mathrm{x}}$ & $0.13^{\mathrm{b}, \mathrm{x}}$ & $0.18^{\mathrm{a}, \mathrm{x}}$ & 0.01 \\
Day 7 & $0.34^{\mathrm{a}, \mathrm{x}}$ & $0.33^{\mathrm{a}, \mathrm{x}}$ & $0.17^{\mathrm{bc}, \mathrm{x}}$ & $0.14^{\mathrm{c}, \mathrm{x}}$ & $0.19^{\mathrm{b}, \mathrm{x}}$ & 0.01 \\
SEM & 0.00 & $0.01^{7}$ & $0.01^{7}$ & 0.01 & 0.02 & \\
\hline Cooked meat & \multicolumn{7}{c}{ TBARS (mg MDA/kg meat) } \\
\hline Day 0 & $0.19^{\mathrm{a}, \mathrm{z}}$ & $0.15^{\mathrm{b}, \mathrm{y}}$ & $0.13^{\mathrm{b}, \mathrm{z}}$ & $0.11^{\mathrm{bc}, \mathrm{z}}$ & $0.14^{\mathrm{b}, \mathrm{y}}$ & 0.01 \\
Day 3 & $1.42^{\mathrm{a}, \mathrm{y}}$ & $1.08^{\mathrm{b}, \mathrm{x}}$ & $0.57^{\mathrm{c}, \mathrm{y}}$ & $0.28^{\mathrm{d}, \mathrm{y}}$ & $0.97^{\mathrm{b}, \mathrm{x}}$ & 0.06 \\
Day 7 & $2.23^{\mathrm{a}, \mathrm{x}}$ & $1.26^{\mathrm{b}, \mathrm{x}}$ & $0.79^{\mathrm{c}, \mathrm{x}}$ & $0.34^{\mathrm{d}, \mathrm{x}}$ & $0.99^{\mathrm{c}, \mathrm{x}}$ & 0.05 \\
SEM & 0.06 & 0.10 & 0.03 & 0.01 & 0.03 & \\
\hline
\end{tabular}

a-d Values with different letters within a row are significantly different $(p<0.05) . n=4$; $^{\mathrm{x}-\mathrm{z}}$ Values with different letters within a column are significantly different $(p<0.05)$. Abbreviation: SEM, standard error of the mean; BHA, butylated hydroxyanisole; TBARS, 2-thiobabituric acid reactive substances; MDA, malondialdehyde.

Research using tannic acid in cooked meat products has been very scarce until recently. The initial TBARS values in cooked meat showed that all treatments added with tannic or BHA showed significant antioxidant effects (Table 1). The initial TBARS values of cooked meat were similar to those of the raw meat, but rapidly increased during storage, especially in control. Under oxygen permeable conditions, cooked meat oxidized very rapidly because of the denaturation of antioxidant enzymes and the structural damages in the membrane during cooking, which can expose phospholipids to the pro-oxidant environment $[11,36]$. Therefore, the difference in lipid oxidation between treatments in cooked meat became clearer than the raw meat. The greatest antioxidant effect was observed when 10 ppm tannic acid was added to the meat. Maqsood and Benjakul [20] also found that tannic acid can be a good additive that retarded the initiation and propagation steps of lipid oxidation reaction when added to the ground beef meat. In addition, they found that the tannic acid radical was characterized as stable and had low energy or low activity to initiate oxidation of unsaturated fatty acid which 
increased its effectiveness [27]. Tannic acid at $10 \mathrm{ppm}$ had a stronger antioxidant effect than 5 ppm tannic acid and 5 ppm BHA at day 7 of storage (Table 1). This suggested that tannic acid could be a good replacement for synthetic antioxidant in foods.

\subsection{Protein Oxidation}

Protein and lipid oxidation are major concerns that affect meat quality during storage [37]. It has been reported that protein oxidation can lead to changes in overall properties of meat proteins such as gelation, viscosity, solubility, and emulsification [38]. Little information about the relationships between protein oxidation and their effect on some meat quality attributes is available. In this study, different levels of tannic acid were investigated to study their effect on the total carbonyl formation (nmol/mg of protein). There were no significant differences $(p>0.05)$ in the amount of carbonyl content among the tannic acid treatments in raw chicken breast meat during the first three days of storage (Table 2). The changes of protein oxidation values in raw chicken breast meat during the 7 -day storage period were very low ( 0.54 at day zero to 0.82 at day 7 for control samples). This was in agreement with Xiao et al. [39] who found that the total carbonyl content in raw chicken meat patties stored aerobically at $4{ }^{\circ} \mathrm{C}$ increased from 0.46 to $0.81 \mathrm{nmol} / \mathrm{mg}$ of protein. Tannic acid at level 10 ppm was the only treatment that showed a significant antioxidant effect $(p<0.05)$ at day 7 of storage. Maqsood and Benjakul [20] found that tannic acid reduced the degradation of myosin heavy chain and actin in meat by suppressing microbial growth during storage. This indicated that the antimicrobial effect of tannic acid could have contributed to the lower total carbonyl formation in meat with different levels of tannic acid. On the other hand, the formation of secondary products (carbonyl and others) of protein oxidation is also related to the degree of lipid oxidation because lipid oxidation is directly related to protein oxidation [40].

Table 2. Protein oxidation of raw and cooked chicken breast meat with different levels of tannic acid during storage at $4{ }^{\circ} \mathrm{C}$.

\begin{tabular}{|c|c|c|c|c|c|c|}
\hline Time & $\begin{array}{l}\text { Control } \\
\text { (None) }\end{array}$ & $\begin{array}{c}2.5 \mathrm{ppm} \\
\text { Tannic }\end{array}$ & $\begin{array}{l}5 \text { ppm } \\
\text { Tannic }\end{array}$ & $\begin{array}{l}10 \text { ppm } \\
\text { Tannic }\end{array}$ & $\begin{array}{c}5 \text { ppm } \\
\text { BHA }\end{array}$ & SEM \\
\hline Raw meat & \multicolumn{6}{|c|}{ Carbonyl content (nmole/mg protein) } \\
\hline Day 0 & $0.54^{\mathrm{a}, \mathrm{y}}$ & $0.54^{\mathrm{a}, \mathrm{y}}$ & $0.52^{a, y}$ & $0.52^{a, x}$ & $0.53^{a, y}$ & 0.03 \\
\hline Day 3 & $0.72^{a, x}$ & $0.72^{a, x}$ & $0.70^{\mathrm{a}, \mathrm{x}}$ & $0.64^{\mathrm{a}, \mathrm{x}}$ & $0.71^{\mathrm{a}, \mathrm{x}}$ & 0.06 \\
\hline Day 7 & $0.82^{a, x}$ & $0.81^{a, x}$ & $0.77^{a, x}$ & $0.66^{\mathrm{b}, \mathrm{x}}$ & $0.77^{a, x}$ & 0.02 \\
\hline SEM & 0.04 & 0.04 & 0.03 & 0.04 & 0.03 & \\
\hline Cooked meat & \multicolumn{6}{|c|}{ Carbonyl content (nmole/mg protein) } \\
\hline Day 0 & $0.58^{a, z}$ & $0.57^{a, y}$ & $0.46^{a, x}$ & $0.45^{a, y}$ & $0.47^{\mathrm{a}, \mathrm{y}}$ & 0.07 \\
\hline Day 3 & $1.21^{a, y}$ & $1.13^{a, x y}$ & $0.62^{b, x}$ & $0.59^{b, x y}$ & $0.80^{b, x}$ & 0.05 \\
\hline Day 7 & $2.01^{a, x}$ & $1.38^{b, x}$ & $0.64^{c, x}$ & $0.60^{c, x}$ & $0.82^{c, x}$ & 0.10 \\
\hline SEM & 0.03 & 0.14 & 0.08 & 0.04 & 0.03 & \\
\hline
\end{tabular}

a-c Values with different letters within a row are significantly different $(p<0.05) . n=4{ }^{\mathrm{x}-\mathrm{z}}$ Values with different letters within a column are significantly different $(p<0.05)$. Abbreviation: SEM, standard error of the mean; BHA, butylated hydroxyanisole.

The total carbonyl values of control cooked meat were higher than those of the raw meat after 3 days of storage and reached up to $2 \mathrm{nmol} / \mathrm{mg}$ protein after 7 days of storage (Table 2). Other researchers reported that total estimated carbonyl contents were in the range of $1-3 \mathrm{nmol} / \mathrm{mg}$ protein for raw meat and up to $5 \mathrm{nmol} / \mathrm{mg}$ protein for cooked meat products [41,42]. Adding tannic acid at 10 ppm successfully delayed the total carbonyl formation in cooked meat during storage. However, tannic acids at 5 and 10 ppm were more effective than other treatments in inhibiting carbonyl formation during storage. These results agreed well with the TBARS values of cooked ground chicken meat during storage. Understanding the mechanism of tannic acid in preventing protein oxidation still 
needs further investigation, but the iron-chelating activity of tannic acid could be a major reason for delaying total carbonyl formation in meat [24,43].

\subsection{Color Values}

Chicken breast meat contains much lower myoglobin content than meats from other animal species such as beef, goat, pork and sheep. Meat color is an important quality parameter that affects the consumer's purchase decision [7]. However, little research was done on the color of ground chicken meat [44]. Table 3 showed that $L^{*}$-values of meat decreased significantly $(p<0.05)$ during storage regardless of treatments. There were no significant differences $(p>0.05)$ in $L^{*}$-values among the treatments at days 0 and 3 of storage. Tannic acid at $10 \mathrm{ppm}$ showed the stronger effect on $\mathrm{L}^{*}$-value than other treatments: the breast meat added with $10 \mathrm{ppm}$ tannic acid had the highest $\mathrm{L}^{*}$-value (lighter meat), and the control had the lowest value (darker meat) at Day 7. The meat with high lightness value is considered more acceptable by the consumer than the darker one because it can be considered old or spoiled [45]. Regardless of treatments, $\mathrm{a}^{*}$-values decreased during storage. However, no significant difference was found $(p>0.05)$ between treatments at day 0 . This agreed with the results of Xiao et al. [39] who reported that $a^{*}$ - and $L^{*}$-values of ground chicken meat decreased significantly after 7 days of refrigerated storage. Mancini and Hunt [6] reported that the decrease of a*-value during storage is due to the accumulation of metmyoglobin pigment. Tannic acid at 10 ppm showed a greater effect in preventing changes of $a^{*}$-value than all other treatments but 5 ppm tannic acid after 3 days of storage. This is in agreement with the results of Maqsood and Benjakul [20] who found that all ground beef samples treated with tannic acid had higher oxymyoglobin and $a^{*}$-value, and received a higher likeness score for color in the sensory evaluation. However, there was no significant difference in $\mathrm{a}^{*}$-value between tannic acid levels at 5 and 10 ppm tannic acid, and 5 ppm BHA during storage. In comparison, Luciano et al. [46] found that dietary tannins improved lamb minced-meat color stability and their shelf life. Changes in $\mathrm{b}^{*}$-values in chicken breast meat during storage were not significant even though tannic acid-treated meat showed higher values than control.

Table 3. CIE color values of raw chicken breast meat with different levels of tannic acid during storage at $4{ }^{\circ} \mathrm{C}$.

\begin{tabular}{|c|c|c|c|c|c|c|}
\hline Time & $\begin{array}{l}\text { Control } \\
\text { (None) }\end{array}$ & $\begin{array}{c}2.5 \mathrm{ppm} \\
\text { Tannic }\end{array}$ & $\begin{array}{l}5 \text { ppm } \\
\text { Tannic }\end{array}$ & $\begin{array}{l}10 \text { ppm } \\
\text { Tannic }\end{array}$ & $\begin{array}{c}5 \text { ppm } \\
\text { BHA }\end{array}$ & SEM \\
\hline \multicolumn{7}{|l|}{$\mathrm{L}^{*}$-value } \\
\hline Day 0 & $64.52^{\mathrm{a}, \mathrm{x}}$ & $64.28^{a, x}$ & $64.32^{a, x}$ & $64.40^{a, x}$ & $64.32^{\mathrm{a}, \mathrm{x}}$ & 0.17 \\
\hline Day 3 & $63.87^{a, x}$ & $63.74^{a, x}$ & $63.63^{a, y}$ & $64.04^{\mathrm{a}, \mathrm{x}}$ & $63.64^{a, y}$ & 0.14 \\
\hline Day 7 & $61.44^{b, y}$ & $62.45^{a b, y}$ & $62.58^{a, z}$ & $63.27^{a, y}$ & $62.44^{\mathrm{ab}, \mathrm{z}}$ & 0.24 \\
\hline SEM & 0.29 & 0.16 & 0.14 & 0.18 & 0.08 & \\
\hline \multicolumn{7}{|l|}{$\mathrm{a}^{*}$-value } \\
\hline Day 0 & $8.53^{a, x}$ & $8.45^{\mathrm{a}, \mathrm{x}}$ & $8.43^{a, x}$ & $8.41^{\mathrm{a}, \mathrm{x}}$ & $8.43^{a, x}$ & 0.14 \\
\hline Day 3 & $6.50^{b, y}$ & $6.42^{b, y}$ & $6.71^{a b, y}$ & $7.00^{a, y}$ & $6.40^{b, y}$ & 0.10 \\
\hline Day 7 & $6.09^{b, z}$ & $6.07^{b, y}$ & $6.43^{a b, y}$ & $6.91^{\mathrm{a}, \mathrm{y}}$ & $6.35^{a b, y}$ & 0.15 \\
\hline SEM & 0.09 & 0.20 & 0.09 & 0.12 & 0.13 & \\
\hline \multicolumn{7}{|l|}{$\mathrm{b}^{*}$-value } \\
\hline Day 0 & $20.09^{b, x}$ & $20.14^{b, x}$ & $19.63^{b, x}$ & $21.33^{a, x}$ & $20.21^{b, x}$ & 0.15 \\
\hline Day 3 & $19.03^{c, y}$ & $19.02^{c, y}$ & $19.75^{b c, x}$ & $21.41^{a, x}$ & $20.43^{a b, x}$ & 0.27 \\
\hline Day 7 & $20.34^{a b, x}$ & $20.26^{a b, x}$ & $19.88^{b, x}$ & $20.81^{a, x}$ & $20.53^{a b, x}$ & 0.20 \\
\hline SEM & 0.19 & 0.18 & 0.29 & 0.21 & 0.16 & \\
\hline
\end{tabular}

a-c Values with different letters within a row are significantly different $(p<0.05) . n=4 ;^{\mathrm{x}-\mathrm{z}}$ Values with different letters within a column are significantly different $(p<0.05)$. Abbreviation: SEM, standard error of the mean; BHA, butylated hydroxyanisole. 


\subsection{Volatiles Production}

At day 0 , the addition of more than $5 \mathrm{ppm}$ tannic acid significantly reduced the amounts of pentane, heptane, pentanal and hexanal produced in the cooked chicken meat compared to the control. Addition of BHA also reduced the amounts of pentane, ethanol, pentanal and hexanal in the cooked meat (Table 4). Hexanal increased rapidly in cooked meat during storage due to a high degree of lipid oxidation. Many lipid oxidation-related aldehydes such as propanal, hexanal, and pentanal were also detected during storage of cooked meat. After 3 days of storage, tannic acid at 5 and 10 ppm showed the most significant effect on the formation of most of these volatiles (Tables 5 and 6). For example, tannic acid at $10 \mathrm{ppm}$ significantly decreased pentane, octane, hexanal, and pentanal formation during storage. Hexanal, which is considered as a good indicator for lipid oxidation [47,48], was significantly affected by 10 ppm of tannic acid at Day 7 of storage (Table 6). Heptanal and nonanal were formed and increased only in control and $2.5 \mathrm{ppm}$ tannic acid-added samples (Tables 5 and 6). Tannic acid at $10 \mathrm{ppm}$ showed the strongest effect in preventing aldehydes' formation in cooked meat. This was in agreement with and reflected the positive relationships between the aldehydes and the degree of lipid oxidation as reported by Nam et al. [49] (Tables 1 and 6). Similar effects on the heptanal and nonanal formation were seen when $10 \mathrm{ppm}$ of tannic acid was added to the cooked meat. Overall, the profile of volatiles indicated that tannic acid at 5 and $10 \mathrm{ppm}$ effectively delayed the formation of lipid oxidation-related volatiles in cooked chicken breast meat during storage.

Table 4. Volatile profiles of cooked chicken breast meat with different level of tannic acid at day 0.

\begin{tabular}{ccccccc}
\hline Compounds & $\begin{array}{c}\text { Control } \\
\text { (None) }\end{array}$ & $\begin{array}{c}\mathbf{2 . 5} \mathbf{~ p p m} \\
\text { Tannic }\end{array}$ & $\begin{array}{c}\mathbf{5} \mathbf{~ p p m} \\
\text { Tannic }\end{array}$ & $\begin{array}{c}\mathbf{1 0} \mathbf{~ p p m} \\
\text { Tannic }\end{array}$ & $\begin{array}{c}\mathbf{5} \mathbf{~ p p m} \\
\text { BHA }\end{array}$ & SEM \\
\hline & & \multicolumn{5}{c}{ Total ion counts $\times 10^{4}$} \\
Pentane & $238^{\mathrm{a}}$ & $240^{\mathrm{a}}$ & $0^{\mathrm{b}}$ & $0^{\mathrm{b}}$ & $0^{\mathrm{b}}$ & 38 \\
2-Propanone & $5267^{\mathrm{a}}$ & $3407^{\mathrm{a}}$ & $3325^{\mathrm{a}}$ & $4171^{\mathrm{a}}$ & $1923^{\mathrm{a}}$ & 1057 \\
Ethanol & $8757^{\mathrm{a}}$ & $8805^{\mathrm{a}}$ & $8302^{\mathrm{a}}$ & $8483^{\mathrm{a}}$ & $3557^{\mathrm{b}}$ & 830 \\
2-Propanol & $810^{\mathrm{a}}$ & $551^{\mathrm{a}}$ & $564^{\mathrm{a}}$ & $494^{\mathrm{a}}$ & $779^{\mathrm{a}}$ & 142 \\
Hexane & $331^{\mathrm{b}}$ & $277^{\mathrm{b}}$ & $144^{\mathrm{bc}}$ & $24^{\mathrm{c}}$ & $830^{\mathrm{a}}$ & 50 \\
Heptane & $56^{\mathrm{ab}}$ & $50^{\mathrm{b}}$ & $0^{\mathrm{c}}$ & $0^{\mathrm{c}}$ & $85^{\mathrm{a}}$ & 7 \\
Pentanal & $566^{\mathrm{a}}$ & $69^{\mathrm{b}}$ & $0^{\mathrm{b}}$ & $0^{\mathrm{b}}$ & $0^{\mathrm{b}}$ & 51 \\
Octane & $274^{\mathrm{a}}$ & $148^{\mathrm{ab}}$ & $143^{\mathrm{ab}}$ & $54^{\mathrm{b}}$ & $162^{\mathrm{ab}}$ & 31 \\
Hexanal & $1761^{\mathrm{a}}$ & $1447^{\mathrm{a}}$ & $78^{\mathrm{b}}$ & $0^{\mathrm{b}}$ & $162^{\mathrm{b}}$ & 174 \\
\hline
\end{tabular}

a-c Values with different letters within a row are significantly different $(p<0.05) . n=4$. Abbreviation: SEM, standard error of the mean; BHA, butylated hydroxyanisole.

Table 5. Volatile profiles of cooked chicken breast meat with different levels of tannic acid at day 3.

\begin{tabular}{ccccccc}
\hline Compounds & $\begin{array}{c}\text { Control } \\
\text { (None) }\end{array}$ & $\begin{array}{c}\mathbf{2 . 5} \mathbf{~ p p m} \\
\text { Tannic }\end{array}$ & $\begin{array}{c}\mathbf{5} \text { ppm } \\
\text { Tannic }\end{array}$ & $\begin{array}{c}\text { 10 ppm } \\
\text { Tannic }\end{array}$ & $\begin{array}{c}\text { 5 ppm } \\
\text { BHA }\end{array}$ & SEM \\
\hline Pentane & $912^{\mathrm{a}}$ & $766^{\mathrm{a}}$ & $0^{\mathrm{b}}$ & $0^{\mathrm{b}}$ & $0^{\mathrm{b}}$ & 50 \\
Propanal & $1459^{\mathrm{a}}$ & $981^{\mathrm{a}}$ & $0^{\mathrm{b}}$ & $0^{\mathrm{b}}$ & $0^{\mathrm{b}}$ & 152 \\
2-Propanone & $3792^{\mathrm{b}}$ & $2283^{\mathrm{b}}$ & $5796^{\mathrm{a}}$ & $5638^{\mathrm{a}}$ & $2674^{\mathrm{b}}$ & 403 \\
Ethanol & $5466^{\mathrm{a}}$ & $6959^{\mathrm{a}}$ & $4546^{\mathrm{ab}}$ & $6540^{\mathrm{a}}$ & $2845^{\mathrm{b}}$ & 576 \\
2-Propanol & $4826^{\mathrm{b}}$ & $8903^{\mathrm{a}}$ & $8552^{\mathrm{a}}$ & $4842^{\mathrm{b}}$ & $5671^{\mathrm{b}}$ & 461 \\
Heptane & $410^{\mathrm{a}}$ & $303^{\mathrm{a}}$ & $0^{\mathrm{b}}$ & $0^{\mathrm{b}}$ & $0^{\mathrm{b}}$ & 31 \\
Pentanal & $3916^{\mathrm{a}}$ & $1732^{\mathrm{b}}$ & $0^{\mathrm{c}}$ & $0^{\mathrm{c}}$ & $110^{\mathrm{c}}$ & 115 \\
Octane & $171^{\mathrm{a}}$ & $60^{\mathrm{b}}$ & $61^{\mathrm{b}}$ & $0^{\mathrm{b}}$ & $149^{\mathrm{a}}$ & 17 \\
Hexanal & $11755^{\mathrm{a}}$ & $9757^{\mathrm{a}}$ & $257^{\mathrm{b}}$ & $0^{\mathrm{b}}$ & $924^{\mathrm{b}}$ & 559 \\
Heptanal & $64^{\mathrm{a}}$ & $56^{\mathrm{a}}$ & $0^{\mathrm{b}}$ & $0^{\mathrm{b}}$ & $0^{\mathrm{b}}$ & 3 \\
Nonanal & $77^{\mathrm{a}}$ & $47^{\mathrm{b}}$ & $0^{\mathrm{c}}$ & $0^{\mathrm{c}}$ & $0^{\mathrm{c}}$ & 4 \\
\hline
\end{tabular}

a-c Values with different letters within a row are significantly different $(p<0.05) . n=4$. Abbreviation: SEM, standard error of the mean; BHA, butylated hydroxyanisole. 
Table 6. Volatile profiles of cooked chicken breast meat with different levels of tannic acid at day 7.

\begin{tabular}{ccccccc}
\hline Compounds & $\begin{array}{c}\text { Control } \\
\text { (None) }\end{array}$ & $\begin{array}{c}\text { 2.5 ppm } \\
\text { Tannic }\end{array}$ & $\begin{array}{c}\text { 5 ppm } \\
\text { Tannic }\end{array}$ & $\begin{array}{c}\text { 10 ppm } \\
\text { Tannic }\end{array}$ & $\begin{array}{c}\text { 5 ppm } \\
\text { BHA }\end{array}$ & SEM \\
\hline Pentane & $1195^{\mathrm{b}}$ & $2349^{\mathrm{a}}$ & $0^{\mathrm{c}}$ & $0^{\mathrm{c}}$ & $0^{\mathrm{c}}$ & 101 \\
Propanal & $350^{\mathrm{a}}$ & $310^{\mathrm{a}}$ & $0^{\mathrm{b}}$ & $0^{\mathrm{b}}$ & $0^{\mathrm{b}}$ & 19 \\
2-Propanone & $6506^{\mathrm{a}}$ & $4420^{\mathrm{ab}}$ & $3682^{\mathrm{ab}}$ & $3348^{\mathrm{b}}$ & $3873^{\mathrm{ab}}$ & 662 \\
2-Propanol & $9122^{\mathrm{a}}$ & $1354^{\mathrm{b}}$ & $1435^{\mathrm{b}}$ & $1438^{\mathrm{b}}$ & $1364^{\mathrm{b}}$ & 249 \\
1-Propanol & $2625^{\mathrm{a}}$ & $1228^{\mathrm{b}}$ & $1377^{\mathrm{b}}$ & $1440^{\mathrm{b}}$ & $1322^{\mathrm{b}}$ & 172 \\
Heptane & $302^{\mathrm{a}}$ & $144^{\mathrm{ab}}$ & $0^{\mathrm{b}}$ & $0^{\mathrm{b}}$ & $0^{\mathrm{b}}$ & 42 \\
Pentanal & $3849^{\mathrm{a}}$ & $4148^{\mathrm{a}}$ & $0^{\mathrm{b}}$ & $0^{\mathrm{b}}$ & $126^{\mathrm{b}}$ & 225 \\
Octane & $776^{\mathrm{a}}$ & $407^{\mathrm{b}}$ & $56^{\mathrm{bc}}$ & $0^{\mathrm{c}}$ & $200^{\mathrm{bc}}$ & 83 \\
Hexanal & $67351^{\mathrm{a}}$ & $51368^{\mathrm{b}}$ & $621^{\mathrm{c}}$ & $0^{\mathrm{c}}$ & $1328^{\mathrm{c}}$ & 537 \\
Heptanal & $252^{\mathrm{a}}$ & $223^{\mathrm{a}}$ & $0^{\mathrm{b}}$ & $0^{\mathrm{b}}$ & $0^{\mathrm{b}}$ & 8 \\
Nonanal & $101^{\mathrm{a}}$ & $76^{\mathrm{ab}}$ & $0^{\mathrm{b}}$ & $0^{\mathrm{b}}$ & $0^{\mathrm{b}}$ & 18 \\
\hline
\end{tabular}

${ }^{a-c}$ Values with different letters within a row are significantly different $(p<0.05) . n=4$. Abbreviation: SEM, standard error of the mean; BHA, butylated hydroxyanisole.

\section{Conclusions}

Tannic acid at 5 or $10 \mathrm{ppm}$ could be effective in maintaining meat color and retarding lipid and protein oxidation, and off-odor-related volatile formation in ground chicken breast during storage. Therefore, tannic acid could be a good candidate as a natural antioxidant to prevent oxidative and color changes in raw and cooked chicken breast meat during storage.

Acknowledgments: This study was supported by the Department of Animal Science, Iowa State University, Ames, Iowa; United States and Foreign Scholarship Division, Department of Scholarship, Mu'tah University, Al-Karak, Jordan.

Author Contributions: Eun Joo Lee and Dong Uk Ahn conceived and designed the experiments; Marwan Alhijazeen performed the experiments and wrote the paper; Aubrey Mendonca, Eun Joo Lee, and Dong Uk Ahn contributed to reagents/materials/analysis tools.

Conflicts of Interest: The authors declare no conflict of interest.

\section{References}

1. Solomakos, N.; Govaris, A.; Koidis, P.; Botsoglou, N. The antimicrobial effect of thyme essential oil, nisin, and their combination against Listeria monocytogenes in minced beef during refrigerated storage. Food Microbiol. 2008, 25, 120-127. [CrossRef] [PubMed]

2. Naveena, B.M.; Sen, A.R.; Vaithiyanathan, S.; Babji, Y.; Kondaiah, N. Comparative efficacy of pomegranate juice, pomegranate rind power extract and BHT as antioxidants in cooked chicken patties. Meat Sci. 2008, 80, 1304-1308. [CrossRef] [PubMed]

3. Abdel-Hamied, A.A.; Nassar, A.G.; El-Badary, N. Investigation on antioxidant and antibacterial activities of some natural extracts. World J. Food Sci. 2009, 4, 1-7.

4. Karre, L.; Lopez, K.; Getty, J.K. Natural antioxidants in meat and poultry products. Meat Sci. 2013, 94, 220-227. [CrossRef] [PubMed]

5. Liu, Q.; Lanari, M.C.; Schaefer, D.M. A review of dietary vitamin E supplementation for improvement of beef quality. J. Anim. Sci. 1995, 73, 3131-3140. [PubMed]

6. Mancini, R.A.; Hunt, M.C. Current research in meat color. Meat Sci. 2005, 71, 100-121. [CrossRef] [PubMed]

7. Bekhit, A.E.D.; Faustman, C. Metmyoglobin reducing activity. Meat Sci. 2005, 71, 407-439. [CrossRef] [PubMed]

8. Nam, K.C.; Ko, K.Y.; Min, B.R.; Ismail, H.; Lee, E.J.; Cordray, J.; Ahn, D.U. Effect of oleoresin-tocopherol combinations on lipid oxidation, off-odor, and color of irradiated raw and cooked pork patties. Meat Sci. 2007, 75, 61-70. [CrossRef] [PubMed]

9. Min, B.; Ahn, D.U. Mechanism of lipid peroxidation in meat and meat products-A review. Food Sci. Biotechnol. 2005, 14, 152-163. 
10. Hall, G. Interactions between products of lipid oxidation and proteins. Food Sci. Technol. Today 1987, 1, 155-158.

11. Gray, J.I.; Gomaa, E.A.; Buckley, D.J. Oxidative quality and shelf life of meats. Meat Sci. 1996, 43, 111-123. [CrossRef]

12. Ahn, D.U.; Nam, K.C.; Lee, E.J. Lipid oxidation and flavor. In Applied Muscle Biology and Meat Science; Du, M., McCormick, R., Eds.; CRC Press: New York, NY, USA, 2009; pp. 227-246.

13. Sebranek, J.G.; Sewalt, V.J.; Robbins, K.L.; Houser, T.A. Comparison of a natural rosemary extract and BHA/BHT for relative antioxidant effectiveness in pork sausage. Meat Sci. 2005, 69, 289-296. [CrossRef] [PubMed]

14. Rojas, M.C.; Brewer, M.S. Effect of natural antioxidants on oxidative stability of frozen, vacuum-packaged beef and pork. J. Food Qual. 2008, 31, 173-188. [CrossRef]

15. Carpenter, R.; O'Grady, M.N.; O'Callaghan, Y.C.; O'Brien, N.M.; Kerry, J.P. Evaluation of the antioxidant potential of grape seed and bearberry extract in raw and cooked pork. Meat Sci. 2007, 76, 604-610. [CrossRef] [PubMed]

16. Brannan, R.G. Effect of grape seed extract on physicochemical properties of ground, salted, chicken thigh meat during refrigerated storage at different relative humidity levels. J. Food Sci. 2008, 73, C36-C40. [CrossRef] [PubMed]

17. Lee, E.J.; Ahn, D.U. Quality characteristics of irradiated turkey breast rolls formulated with plum extract. Meat Sci. 2005, 71, 300-305. [CrossRef] [PubMed]

18. Salminen, J.P.; Karonen, M.; Sinkkonen, J. Chemical ecology of tannins: recent developments in tannin chemistry reveal new structures and structure-activity patterns. Chem. Eur. J. 2011, 17, 2806-2816. [CrossRef] [PubMed]

19. Hagerman, A.E. Hydrolyzable tannin structural chemistry. In The Tannin Handbook; Miami University: Oxford, OH, USA, 2011; pp. 1-8.

20. Maqsood, S.; Benjakul, S. Preventive effect of tannic acid in combination with modified atmospheric packaging on the quality losses of the refrigerated ground beef. Food Control 2010, 21, 1282-1290. [CrossRef]

21. Bate-smith, E.C.; Swain, T. Flavonoid compounds. In Comparative Biochemistry; Florkin, M., Mason, H.S., Eds.; Academic Press: New York, NY, USA, 1962; pp. 755-809.

22. Okuda, T.; Ito, H. Tannins of constant structure in medicinal and food plants-hydrolyzable tannins and polyphenols. Molecules 2011, 16, 2191-2217. [CrossRef]

23. Chung, K.T.; Wong, T.Y.; Wei, C.I.; Hang, Y.W.; Lin, Y. Tannin and human health: A review. Food Sci. Nutr. 1998, 38, 421-464. [CrossRef] [PubMed]

24. Lopes, G.; Schulman, H.; Hermes-Lima, M. Polyphenol tannic acid inhibits hydroxyl radical formation from Fenton reaction by complexing ferrous ions. Biochim. Biophys. Acta 1999, 1472, 142-152. [CrossRef]

25. Gulcin, I.; Huyut, Z.; Elmastas, M.; Aboul-Enein, H.Y. Radical scavenging and antioxidant activity of tannic acid. Arabian J. Chem. 2010, 3, 43-53. [CrossRef]

26. Maqsood, S.; Benjakul, S. Comparative studies of four different phenolic compounds on in vitro antioxidant activity and the preventive effect on lipid oxidation of fish oil emulsion and fish mince. Food Chem. 2010, 119, 123-132. [CrossRef]

27. Maqsood, S.; Benjakul, S. Synergistic effect of tannic acid and modified atmospheric packaging on the prevention of lipid oxidation and quality losses of refrigerated striped catfish slices. Food Chem. 2010, 121, 29-38. [CrossRef]

28. Food and Drug Administration (FDA). Direct Food Substances Affirmed as Generally Recognized as Safe, Code of Federal Regulation. Available online: https:/ / www.accessdata.fda.gov/scripts/cdrh/cfdocs/cfcfr/ CFRSearch.cfm?fr=184.1097 (accessed on 28 April 2016).

29. United States Department of Agriculture (USDA). Guidelines for Establishing and Operating Poultry Processing Plants; USDA-ARS: Washington, DC, USA, 1982.

30. Ahn, D.U.; Olson, D.G.; Jo, C.; Chen, X.; Wu, C.; Lee, J.I. Effect of muscle type, packaging, and irradiation on lipid oxidation, volatile production and color in raw pork patties. Meat Sci. 1998, 49, 27-39. [CrossRef]

31. AMSA (American Meat Science Association). Guideline for meat color evaluation. In Proceedings of the 44th Reciprocal Meat Conference, Manhattan, KS, USA, 9-12 June 1991; National Live Stock and Meat Board: Chicago, USA, 1992; pp. 1-17. 
32. Ahn, D.U.; Nam, K.C.; Du, M.; Jo, C. Volatile production in irradiated normal, pale soft exudative (PSE) and dark firm dry (DFD) pork under different packaging and storage conditions. Meat Sci. 2001, 57, 419-426. [CrossRef]

33. Lund, M.N.; Hviid, M.S.; Claudi-Magnussen, C.; Skibsted, L.H. Effects of dietary soybean oil on lipid and protein oxidation in pork patties during chill storage. Meat Sci. 2008, 79, 727-733. [CrossRef] [PubMed]

34. Levine, R.L.; Williams, J.A.; Stadtman, E.R.; Shacter, E. Carbonyl assays for determination of oxidatively modified proteins. Methods Enzymol. 1994, 233, 346-357. [PubMed]

35. SAS Institute Inc. Cary, NC: SAS Institute Inc. Base SAS ${ }^{\circledR}$ 9.3; SAS Institute Inc.: Cary, NC, USA, 2012.

36. Ahn, D.U.; Wolfe, F.H.; Sim, J.S.; Kim, D.H. Packaging cooked turkey meat patties while hot reduced lipid oxidation. J. Food Sci. 1992, 57, 1075-1077. [CrossRef]

37. Nieto, G.; Jongberg, S.; Anderson, M.L.; Skibsted, L.H. Thiol oxidation and protein cross-link formation during chill storage of pork patties added essential oil of oregano, rosemary, or garlic. Meat Sci. 2013, 95, 177-184. [CrossRef] [PubMed]

38. Xiong, Y.L. Protein oxidation and implications for muscle foods quality. In Antioxidants in Muscle Foods; Decker, E.A., Faustman, C., Lopez-Bote, C.J., Eds.; Wiley: New York, NY, USA, 2000; pp. 85-111.

39. Xiao, S.; Zhang, W.G.; Lee, E.J.; Ma, C.W.; Ahn, D.U. Effect of diet, packaging, and irradiation on protein oxidation, lipid oxidation, and color of raw broiler thigh meat during refrigerated storage. Poultry Sci. 2011, 90, 1348-1357. [CrossRef] [PubMed]

40. Estevez, M. Protein carbonyls in meat system: A review. Meat Sci. 2011, 89, 259-279. [CrossRef] [PubMed]

41. Estevez, M.; Ventanas, S.; Cava, R. Protein oxidation in frankfurters with increasing levels of added rosemary essential oil: Effect on color and texture deterioration. J. Food Sci. 2005, 70, 427-432. [CrossRef]

42. Sun, W.Q.; Zhang, Y.J.; Zhou, G.H.; Xu, X.L.; Peng, Z.Q. Effect of apple polyphenol on oxidative stability of sliced cooked cured beef and pork hams during chilled storage. J. Muscle Food 2010, 21, 722-737. [CrossRef]

43. South, P.K.; Miller, D.D. Iron binding by tannic acid: effect of selected ligands. Food Chem. 1998, 63, 167-172. [CrossRef]

44. Sandusky, C.L.; Heath, J.L. Sensory and instrument-measured ground chicken meat color. Poultry Sci. 1998, 77, 481-486. [CrossRef]

45. Hood, D.E.; Riordan, E.B. Discoloration in pre-packaged beef measurement by reflectance spectrophotometry and shopper discrimination. J. Food Technol. 1973, 8, 333-343. [CrossRef]

46. Luciano, G.; Monahan, F.J.; Vasta, V.; Biond, L.; Lanza, M.; Priolo, A. Dietary tannins improve lamb color stability. Meat Sci. 2009, 81, 120-125. [CrossRef] [PubMed]

47. Shahidi, F.; Yun, J.; Rubin, L.J.; Wood, D.F. The hexanal content as an indicator of oxidative stability and flavor acceptability in cooked ground pork. J. Can. Inst. Food Sci. Technol. 1987, 20, 104-106. [CrossRef]

48. Ahn, D.U.; Jo, C.; Olson, D.G.; Nam, K.C. Quality characteristics of pork patties irradiated and stored in different packaging and storage conditions. Meat Sci. 2000, 56, 203-209. [CrossRef]

49. Nam, K.C.; Ahn, D.U. Use of double-packaging and antioxidant combinations to improve color, lipid oxidation, and volatiles of irradiated raw and cooked turkey breast patties. Poultry Sci. 2003, 82, 850-857. [CrossRef]

(C) 2016 by the authors; licensee MDPI, Basel, Switzerland. This article is an open access article distributed under the terms and conditions of the Creative Commons Attribution (CC-BY) license (http://creativecommons.org/licenses/by/4.0/). 